\title{
The Effect of Learning Technique and Reading Interest Towards Students' Listening Skill
}

\author{
Mida Sulfiana \\ Pendidikan Bahasa Inggris-Universitas Islam Negeri Syarif Hidayatullah Jakarta
}

\begin{tabular}{l}
\hline \hline INFO ARTIKEL \\
\hline Riwayat Artikel: \\
Diterima: 10-05-2019 \\
Disetujui: $25-01-2020$ \\
\hline
\end{tabular}

\section{Kata kunci:}

learning technique; reading interest; English listening skills; teknik pembelajaran; minat baca;

keterampilan menyimak bahasa Inggris

\begin{abstract}
ABSTRAK
Abstract: This research aims to determine the effect of learning technique and reading interest toward students' English listening skill. This research is an experimental type. The instruments used were written tests and questionnaires. The results of this research showed there is an effect between learning techniques and reading interests toward students' Listening skills. There are significant differences between students having high and low reading interest. Those who learned with Dictogloss Technique have higher reading interests than those who learned with Traditional Dictation Technique. Meanwhile, students having low reading interests who learned with Dictogloss Technique and Traditional Dictation have no significant difference in English listening skills.

Abstrak: Penelitian ini bertujuan untuk mengetahui pengaruh teknik pembelajaran dan minat baca terhadap keterampilan menyimak bahasa Inggris mahasiswa. Penelitian ini merupakan jenis penelitian eksperimen. Instrumen yang digunakan adalah instrumen tes dan kuesioner. Hasil penelitian ini menunjukkan bahwa terdapat interaksi antara teknik pembelajaran dan minat baca terhadap keterampilan menyimak bahasa Inggris, terdapat perbedaan keterampilan menyimak antara kelompok mahasiswa dengan minat baca tinggi dan rendah yang belajar dengan teknik dictogloss darpada yang belajar dengan teknik traditional dictation, hasil keterampilan menyimak kelompok mahasiswa dengan minat baca rendah yang belajar dengan teknik dictogloss dan teknik traditional dictation tidak menunjukkan adanya perbedaan yang signifikan.
\end{abstract}

\author{
Alamat Korespondensi: \\ Mida Sulfiana \\ Pendidikan Bahasa Inggris \\ Universitas Islam Negeri Syarif Hidayatullah Jakarta \\ Jalan Ir.H. Juanda No.95, Ciputat \\ E-mail: mida.sulfiana@uinjkt.ac.id
}

Listening is one of the pivotal language skills for English as a Foreign Learner (EFL). It is the one of the vital activities in the classroom because this process serves as input for the students. (Vasiljevic, 2010) stated that in communication, listening skill takes $45 \%$. This shows how important it is for students to have good listening skill as such empower all of their language skill. Hence (Holden, 2015) added that the students would get the advantages of cognitive improvement, efficiency, utility and stimulation, if the learning focuses in listening skill. (Richard, 2001) and (Smith, 2010) stated listening has corelation with another skill, such as reading. Listening and reading are considered as receptive skills. (Harmer, 2001) defined receptive skill as one having an ample understanding of discourse concept. Therefore, (Khairuddin, 2013) assumed that good reading interest could really students in the listening skill process. It is because of the formed schemata that the students get from reading activities. This will be important for them in the comprehension process.

(Brown, 2004) mentioned that there are always difficulties faced by an EFL individual in listening activities; understanding gaps such as phrase and clause (clustering), understanding repeating types and long sentences (redundancy), understanding idiom, slang word and culture knowledge (colloquial language) and understanding stress, rhythm, and intonation (rate of delivery). In general, (Cottrell, 2001) pointed skills are performance qualities which can be obtained through learning and practicing. Moreover, exercises and repetitions will increase students' skills in language. According to Rost in (Gilakjani \& Ahmadi, 2011), defined listening as a process in accepting and constructing what is said by the speaker, then representing and negotiating meaning with the speaker and listener so it can create meaning through the involvement of both. Brindley in (Richard, 2001) divided the domain of listening skills into five, as follows: focusing on spoken text, identifying main ideas, exploring specific information in the text, understanding the structure of text and its parts, and understanding the implicit meaning. Therefore, to improve students' performances and learning outcomes in listening activities, implementing an appropriate learning technique is essential. 
Dictogloss is an interactive teaching technique, which incorporates various activities such as listening, notes taking, discussing, and constructing. Basically, Dictogloss is designed to faciliate students in learning writing skill. (Bataineh, 2016) supported that dictogloss has advantages in communicative notions and concerned in grammar. Moreover, dictogloss can be applied in another skill, such as listening skill. Buck in (Jibir-daura, 2013) stated that listening requires the use both systematic and schematic knowledge. At this stage, students should have sufficient knowledge of language system that can help them in listening process. Moreover, (Alex Wahyu Wibowo, 2012) added dictogloss technique could be a useful way between bottomup and top-down in listening process. The students should recognize the individual components in a text which called bottomup process. With this strategy, the students should intergrate all their background knowledge (schemata) in discussing process.

According to Wajnryb in (Vasiljevic, 2010) there is a four-staged procedure in applying dictogloss, namely: (1) preparation, (2) listening, (3) reconstruction, and (4) analysis and correction. In preparation stage: teacher gives interesting brainstorming activities to the students about the topic of a passage, for the students to actively discuss among themselves or individually introspect. After that, the students are divided into group 4 or 5 . The second stage is dictation. In this stage, students are to read a text for two to three times. In the first session, students are not allowed to write anything except listen to the text. In the next session, students jot important words and phrases on the paper in order to reconstruct the text.

The third stage, reconstruction, is very important for students. Each group is to discuss and try to reconstruct a version of a text from their previous notes. They have to reconstruct the text having the idea similar to the original text. After that, each group presents their works to other groups. During the final stage, the teacher can give feedbacks on the mistakes of the reconstruction result. In addition, (Dewi, 2014)added that dictogloss helps students to use their grammar knowledge to reconstruct a passage. It will help them to be more aware with their grammatical choice when they reconstruct the idea into a new form. Furthermore, dictogloss has multifunction to develop students' listening, writing, and speaking skills.

Traditional dictation technique or better known as dictation is a learning technique where students receive oral input, store it in short-term memory, and then put it back in writing. (Nation \& Newton, 2008) added the length of the given text should be around 100 to 150 words. (Smith, 2010) supported, this technique is also effective in contributing to the improvement of all language skills such as listening, speaking, reading and writing. The difference between the dictogloss and the traditional dictation technique is that dictogloss can facilitate the development of students in competent communicative aspects, while the traditional dictation helps students in understanding the meanings obtained from grammar learning.

(Dai, 2013; Schunk, Dale.H, 2012; Woolfolk, 2009) concluded interest is an attraction or feeling of pleasure in a person towards certain objects or activities, so it becomes a pleasure and consciously carries out an activity with pleasure. (Tomlinson, 2003) defined reading is a process of communication carried out and used by readers to get the message to be conveyed by the author through communication media or written material. In addition, (Khairuddin, 2013) supported that reading interest could be a tendency of desire or interest towards a thing or activity that comes within a person accompanied by strong motivation that makes a person have an interest in reading.

According to (Andayani, 2015), reading process has several aspects including sensory aspects, perceptual aspects, schematic aspects, thinking aspects, and affective aspects. One aspect that is very related to interest is the affective aspect. The affective aspects in reading interest include aspects that identify the dimensions of feeling from emotional awareness, character, and will that has influence to one's thoughts and actions. Furthermore, (Dai, 2013) added that there are cognitive aspects in reading interest refer to the thinking and managing process of the read information in order to gain an understanding of the information. Beside those aspects, there are also conative aspects which are included in the aspects of reading interest. (Cain \& Hutt, 2005) claimed conative aspect refers to the relation of knowledge that has influence to a person's behavior. This aspect evaluates whether there are changes in behavior and actions of a person or not before reading, doing reading, and after reading.

Based on the description above, this study aims to find out more in detail about: (1) Differences in English listening skills between groups of students studying with dictogloss and with traditional dictation techniques; (2) Influence of interaction between learning technique and reading interest in listening skills; (3) Differences in English listening skills in groups of students with high reading interests studying with dictogloss and traditional dictation techniques; (4) Differences in English listening skills in groups of students with low reading interests studying with dictogloss and with traditional dictation techniques.

\section{METHOD}

This study is using the experimental method with two independent variables; they are learning technique and reading interest, while the dependent variable is the student's listening skill. The experimental design used is treatment design by level 2 $X$ 2. Data are analysed by two-way of ANAVA where Ho at the significant level of 0.05 could be rejected.

The population in this study are students at $4^{\text {th }}$ semester of the English Language and Literature Department at UIN Jakarta. Sampling is determined by simple random sampling technique, are (1) selecting two of three classes by randomly raffling, (2) Providing a reading interest questionnaires to find out groups of students with high and low reading interest in the prescribed treatment group. (Stamboel, 1990) suggested that the result of this measurement is taken as many as $27 \%$ of the upper group and $27 \%$ of the lower group. 
The technique of collecting data about reading interest in English is distributing questionnaires to students who are the research samples. To measure students' reading interest in English, here is using questionnaires with 5 alternatives in statements there are always, often, sometimes, rarely and never. Collecting the data on students' English listening skills is using written test instruments in English multiple-choice.

Before conducting data analysis, there are two testing requirements, the normality test using the Liliefors test and the homogeneity test using the Barlett test. Furthermore, testing and analysing the data statistically using two-way of variance analysis (ANAVA) techniques. Hypothesis testing is using the F test at a significant level $\alpha=0.05$. If the critical $\mathrm{F}$ value is significant, there is an interaction between learning technique and reading interest in students' English listening skills. Then, it could be continued by the Tuckey test.

Table 1. Experiment treatment by level 2 × 2 Design

\begin{tabular}{cccc}
\hline \multirow{2}{*}{$\begin{array}{c}\text { Reading } \\
\text { Interest }\end{array}$} & \multicolumn{2}{c}{ Learning Technique } \\
\cline { 2 - 4 } & (Dictogloss Technique) & $\begin{array}{c}\text { Traditional Dictation } \\
\text { Technique }\end{array}$ \\
\hline High & A1B1 & $>$ & A2B1 \\
Low & A1B2 & $<$ & A2B2 \\
Total & A1 & $>$ & A2
\end{tabular}

\section{Explanation:}

A1 : Group of students studying with dictogloss techniques.

A2 : Group of students studying with traditional dictation techniques.

B1 : Group of students with high reading interest.

B2 : Group of students with low reading interest.

$\mathrm{A}_{1} \mathrm{~B}_{1} \quad$ : Group of students studying with dictogloss in high reading interest.

$\mathrm{A}_{1} \mathrm{~B}_{2} \quad$ : Group of students studying with dictogloss in low reading interest.

$\mathrm{A}_{2} \mathrm{~B}_{1} \quad$ : Group of students studying with traditional dictation in high reading interest.

$\mathrm{A}_{2} \mathrm{~B}_{2} \quad$ : Group of students studying with traditional dictation in low reading interest.

\section{RESULT}

In this study, the collected data are the results of tests of students' English listening skills that are the research sample. The described data consisted of six groups: (1) the data of test results of group of students treated with dictogloss ( $\left.\mathrm{A}_{1}\right)$ showing the empirical score is in the lowest range of 12 and the highest of 26 so the range between the highest and lowest is 14 . The average score on listening skills in this group is 21.05 , (2) the data of test results of group of students treated with traditional dictation $\left(\mathrm{A}_{2}\right)$ showing the empirical score is in the lowest range of 10 and the highest of 22 so the range between the highest and the lowest is 12 . The average score on listening skills in this group is 16.35 , (3) the data of test results of group of students treated with dictogloss in high reading interest $\left(\mathrm{A}_{1} \mathrm{~B}_{1}\right)$ showing the empirical score is in the lowest range of 22 and the highest of 26 so the range between the highest and the lowest is 4 . The average score on listening skills in this group is 24.2 , (4) the data of test results of group of students treated with dictogloss in low reading interest $\left(\mathrm{A}_{1} \mathrm{~B}_{2}\right)$ showing the empirical score is in the lowest range of 12 as low as 21 so the range between the two lowest is 9 . The average score on listening skills in this group is $17.90,(5)$ the data of test results of group of students treated with traditional dictation in high reading interest $\left(\mathrm{A}_{2} \mathrm{~B}_{1}\right)$ showing the empirical score is in the lowest range of 14 and the highest of 22 so the range between the highest and the lowest is 8 . The average score on listening skills in this group is 17.40, and (6) the data of test results of group of students treated with traditional dictation in low reading interest $\left(\mathrm{A}_{2} \mathrm{~B}_{2}\right)$ showing the empirical score is in the lowest range of 10 as low as 20 so the range between the lowest is 10 . The average score on listening skills in this group is 15.30 . Data for each group are presented in the form of averages, deviations standards, variances, frequency distribution tables and histograms. Data for each group can be seen in the summary table of the research results as follows:

Table 2. Score Recapitulation of Students' English Listening Skill

\begin{tabular}{ccccccccc}
\hline Group of Data & $\mathbf{n}$ & $\mathbf{( \sum \mathbf { X i } )}$ & $\mathbf{M} / \overline{\boldsymbol{X}}$ & $\mathbf{S D} / \mathbf{S}$ & $\mathbf{S}^{\mathbf{2}}$ & $\mathbf{R}$ & Minimum & Maximum \\
\hline $\mathrm{A}_{1}$ & 20 & 421 & 21,05 & 3,818 & 14,576 & 14 & 12 & 26 \\
$\mathrm{~A}_{1} \mathrm{~B}_{1}$ & 10 & 242 & 24,20 & 1,229 & 1,511 & 4 & 22 & 26 \\
$\mathrm{~A}_{1} \mathrm{~B}_{2}$ & 10 & 179 & 17,90 & 2,685 & 7,211 & 9 & 12 & 21 \\
$\mathrm{~A}_{2}$ & 20 & 327 & 16,35 & 3,150 & 9,924 & 12 & 10 & 22 \\
$\mathrm{~A}_{2} \mathrm{~B}_{1}$ & 10 & 174 & 17,40 & 2,989 & 8,933 & 8 & 14 & 22 \\
$\mathrm{~A}_{2} \mathrm{~B}_{2}$ & 10 & 153 & 15,30 & 3,093 & 9,567 & 10 & 10 & 20
\end{tabular}


Characteristic Test

Testing the requirements of data analysis in this study uses the normality and homogeneity test.

Table 3. Normality Test of Students Using Liliefors Test with 0,05 Significance Level

\begin{tabular}{ccccc}
\hline Group & $\mathbf{N}$ & Score $($ Lo) & Score $(\mathbf{L t})$ & Result \\
\hline A1 & 20 & 0.100 & 0.19 & Normal \\
A2 & 20 & 0.118 & 0.19 & Normal \\
A1B1 & 10 & 0.158 & 0.258 & Normal \\
A1B2 & 10 & 0.124 & 0.258 & Normal \\
A2B1 & 10 & 0.189 & 0.258 & Normal \\
A2B2 & 10 & 0.191 & 0.258 & Normal \\
\hline
\end{tabular}

From the Table.3, it was obvious that the data were distributed normally. It is showed that $\mathrm{L}_{0}=0,100$ less than $\mathrm{L}_{\text {table }}=$ 0.190 for Dictogloss Technique. The calculation result is $\mathrm{L}_{0}<\mathrm{L}_{t}$, so $\mathrm{H}_{0}$ is accepted. It is concluded that all groups are normal. The summary of the variance homogeneity test through Barlett's test of the four groups of data is presented in table 4 .

Table 4. Homogenity Test of Students Using Barlett Test $(\alpha=0,05)$

\begin{tabular}{ccccccc}
\hline Sample & $\mathbf{d k}$ & $\mathbf{1} / \mathbf{d k}$ & $\mathbf{s i}^{\mathbf{2}}$ & Value $\left(\mathbf{X}^{\mathbf{2}}\right.$ value $)$ & Value $\left(\mathbf{X}^{\mathbf{2}}\right.$ table $)$ & Result \\
\hline A1B1 & 9 & 0,1111 & 1,5111 & 7,509 & 7,815 & Homogen \\
A1B2 & 9 & 0,1111 & 7,2111 & & & \\
A2B1 & 9 & 0,1111 & 8,9333 & & & \\
A2B2 & 9 & 0,1111 & 9,5667 & & & \\
Jumlah & 36 & & 27,222 & & & \\
\hline
\end{tabular}

From the table, it is known that $\chi^{2}=7,509<\chi^{2}$ table $=7,815$, then Ho is accepted. This means the four groups have homogeneous variances. It can be concluded the data of listening skills score from the four groups are homogeneous. Based on the results of both normality and homogeneity test above, the data results are sufficient.

\section{Hypothesis Test}

The hypothesis test in this study used Two-Way Analysis of Variance (ANAVA) and was continued by using the Tuckey test because the data in each group were similar.

Table 5. Two-Way Analysis of Variance Recapitulation

\begin{tabular}{|c|c|c|c|c|c|c|}
\hline \multirow{2}{*}{ Variation } & \multirow{2}{*}{ JK } & \multirow{2}{*}{ db } & \multirow{2}{*}{ RJK } & \multirow{2}{*}{ Fo } & \multicolumn{2}{|c|}{ F table } \\
\hline & & & & & 0,05 & $\mathbf{0 , 0 1}$ \\
\hline $\begin{array}{l}\text { Within A (Method) } \\
\text { Within B (Reading } \\
\text { Interest) } \\
\text { AB Interaction } \\
\text { Within Group } \\
\text { In the Group } \\
\text { Total }\end{array}$ & $\begin{array}{c}220,9 \\
176,4 \\
44,1 \\
441,4 \\
245 \\
686,4\end{array}$ & $\begin{array}{c}1 \\
1 \\
1 \\
3 \\
36 \\
39\end{array}$ & $\begin{array}{c}220,900 \\
176,400 \\
44,100 \\
147,133 \\
6,806\end{array}$ & $\begin{array}{c}32,459 \\
25,920 \\
6,480 \\
21,620\end{array}$ & $\begin{array}{l}4,113 \\
2,866\end{array}$ & $\begin{array}{l}7,396 \\
4,377\end{array}$ \\
\hline
\end{tabular}

Based on the results of the calculation of ANAVA, it can be obtained that the results of hypothesis testing at a significant level $\alpha=0.05$ are generated:

1) The group that was learned with dictogloss technique is better than traditional dictation learning techniques. Based on the results of data analysis using two-way of ANAVA with level of significant $\alpha=0.05$, the value of $F$ count (Fo) $=$ 32.459 is greater than $\mathrm{F}$ table $=4.210$, then $\mathrm{H}_{1}$ is accepted. The average of group $\mathrm{A} 1$ (24.2) is greater than group A2 (17.90).

2) There is significant interaction between learning techniques (dictogloss and traditional dictation) and reading interests of students' listening skills.

Based on the result above, it can be obtained at significant level $\alpha=0.05$, the value of $F$ count $(\mathrm{Fo})=6.480$ is greater than $\mathrm{F}$ table $=4.210$, then Ho is rejected and as a consequence $\mathrm{H} 1$ is accepted. The interaction graph can be seen below: 


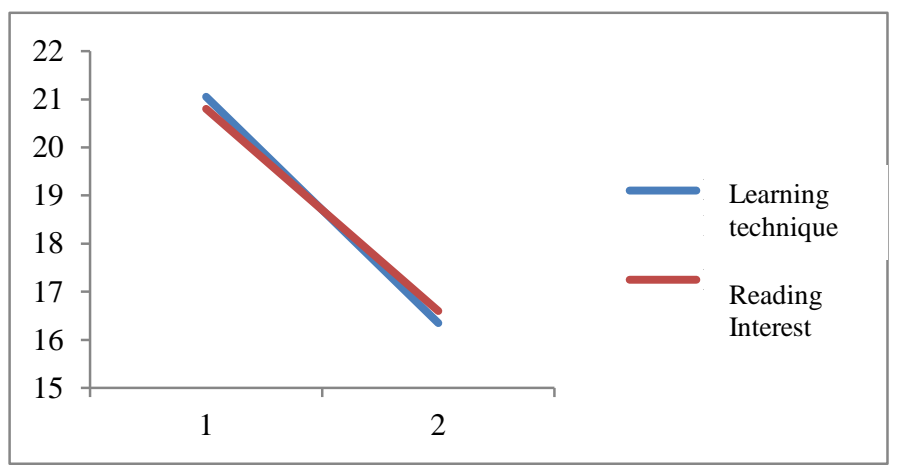

Figure 1. Learning Technique and Reading Interest Interaction

The graph shows there are four points connected by the two intersecting lines. The two intersecting lines indicate there is interaction between the two independent variables, the learning technique (dictogloss and traditional dictation) and reading interest towards the dependent variable, the listening skills. With the existence of a very significant interaction influence between learning technique and reading interest, multiple comparison tests are conducted. This test is intended to find out the average score of which group is significantly different. Because the numbers of samples for each group are the same, the Tukey test is used.

Table 6. Tuckey Test Result

\begin{tabular}{ccccc}
\hline \multicolumn{2}{c}{ Combination } & Q count & Q table & Result \\
\hline A1B1 & A2B1 & 8,24 & 3,20 & Berbeda \\
A2B2 - & A2B2 & 2,55 & 3,95 & Tidak Berbeda \\
\hline
\end{tabular}

1) In the group with high reading interest, the results of students' listening skills with dictogloss are better than the students with traditional dictation.

Based on the calculation results using the Tuckey test obtained for the group of $\mathrm{A}_{1} \mathrm{~B}_{1}$ and $\mathrm{A}_{2} \mathrm{~B}_{1}$ there is value of the Qcount is 8.24 and value of the Qtable with a significant level of $\alpha=0.05 \mathrm{dk}=\mathrm{n}-1=10-1=9$ is 3.95 . The result of data analysis shows between students with high reading interest studying dictogloss and traditional dictation at a significant level of $\alpha=0.05$ mentioned before the Qcount $=8.24$ is greater than Qtable 3.95. This means $\mathrm{H}_{1}$ is accepted because the group of students with high reading interest studying the dictogloss (24.20) is greater than the traditional dictation (17.40).

2) There is no significant difference in the group with low reading interest whether they are studying the dictogloss or the traditional dictation.

The results of calculations using the Tuckey test are obtained for the group of $A_{1} B_{1}$ and $A_{2} B_{1}$, the value of $Q$ count is 2.55 and the value of Qtable with a significant level of $\alpha=0.05 \mathrm{dk}=\mathrm{n}-1=10-1=9$ is 3.95 . This shows among students with low reading interests who are taught the dictogloss and the traditional dictation at a significant level $\alpha=$ 0.05, mentioned before the Qcount $=2.55$ is smaller than Qtable 3.95. This means Ho is accepted and consequently, $\mathrm{H}_{1}$ is rejected. From the differences of the average in the two groups, show the group of students with low reading interest taught the dictogloss have lower listening skills, which are 17.90 while in the traditional dictation have an average listening skill of 15.30 .

The results of calculations using the Tuckey test are obtained for the group of $\mathrm{A}_{1} \mathrm{~B}_{1}$ and $\mathrm{A}_{2} \mathrm{~B}_{1}$, the value of $\mathrm{Q}$ count is 2.55 and the value of Qtable with a significant level of $\alpha=0.05 \mathrm{dk}=\mathrm{n}-1=10-1=9$ is 3.95 . This shows among students with low reading interests who are taught the dictogloss and the traditional dictation at a significant level $\alpha=$ 0.05 , mentioned before the Qcount $=2.55$ is smaller than Qtable 3.95. This means Ho is accepted and consequently, $\mathrm{H}_{1}$ is rejected. From the differences of the average in the two groups, show the group of students with low reading interest taught the dictogloss have lower listening skills, which are 17.90 while in the traditional dictation have an average listening skill of 15.30 .

\section{DISCUSSION}

The Influence of Learning Techniques towards Listening Skill

The use of the dictogloss technique in learning has an influence on students learning outcomes. The result of the first hypothesis stating the null hypothesis is rejected. This means, as a consequence, the proposed research hypothesis is accepted. This is evidenced by the average value of students' listening skills studying the dictogloss is 24.2 , higher than the average value 
of listening skills studying the traditional dictation is 17.90 . The differences in the average values of the listening skills from the two groups with the dictogloss and traditional dictation techniques are caused by different learning processes where the dictogloss emphasizes cooperative or group learning activities. In learning activities with dictogloss students play an active role in understanding, analyzing, making conclusions and conveying information obtained from listening activities. The learning process is also centered on the process of understanding meaning as conveyed by the speaker. In the dictogloss, students are trained to focus on the meaning and structures of language (grammar) both are very helpful in the listening process. On the one hand, students who study traditional dictation learning techniques tend to be passive because of their individual learning processes. In this technique, listening activities rely on students' abilities and schemas. Therefore the results of students' listening skills with the dictogloss are better than the results of students' listening skills with traditional dictation.

The dictogloss technique is a cooperative learning technique where listening activities focus on the process of understanding meaning and integrating with other language skills such as writing, reading and speaking. Learning activities also provide challenges to students in the process of text reconstruction. Students are given the opportunity to discuss during the reconstruction process. In the reconstruction phase, students need to consider the meaning and form of the text to be reconstructed. Therefore, the cooperative learning process applies to this technique where students try to be actively involved in the learning process. Students who don't understand will be motivated and helped by cooperative learning. Students who study with the dictogloss can also be accustomed listening to the pieces of information that are heard then correcting each other's grammatical errors and analyzing errors that are often made on the results of text reconstructions. Then, students are accustomed to do these activities which are very helpful in listening problems. This shows the differences in the results of English listening skills of the two groups.

\section{The Influence of Reading Interests towards Listening Skill}

The results of the null hypothesis testing indicate there is no difference in listening skills between students who have a high reading interest whether study with the dictogloss or with traditional dictation are denied. This means as a consequence, the research hypothesis $\left(\mathrm{H}_{1}\right)$ is accepted. This is indicated by the average of listening skills in the group of students who have a high reading interest with the dictogloss technique is 24.20 greater than the group of students with the traditional dictation is 17.40. Based on the differences in the results of listening skill, it can be explained students who have a high reading interest are greatly benefited if taught the dictogloss learning technique because its cooperative and active learning process. This has an influence on the performance of groups of students with high reading interest who can work optimally in each of their groups by relying on their own schemas. This is due to the process of collaboration in the phase of text reconstruction can help raising the schemata of students with high reading interest, this group will more easily understand the information they are listening because the formed schemata can be used optimally in the listening process.

According to (Harmer, 2001) schemata allows individuals to make guesses and interpretations about events that often occur in well known situations to individuals. This makes the group of students with high reading interest can show better listening performance in the learning process especially with dictogloss techniques. (Vasiljevic, 2010) stated that the reconstruction phases in the dictogloss technique are the most important phases. Reconstruction phases require knowledges in the form of vocabularies and structure of language to assist in the process of compiling coherent texts. Therefore, the schemas possessed by groups of students with high reading interests can facilitate them in the reconstruction process.

On the one hand, groups of students with high reading interests who are taught the traditional dictation techniques can also rely on the schema in understanding the heard information. However, because students work independently in completing assignments, they tend to be influenced by external factors such are worries in completing tasks and the speed of the speaker (rate of delivery). It is concluded the group of students with high reading interests are very beneficial and suitable to learn with the dictogloss technique compared to the traditional dictation. In addition, although both of these learning techniques have their respective advantages towards listening skills, the dictogloss can provide better results than the traditional dictation in groups of students with high reading interest.

\section{The Influence of Learning Technique Interactions and Reading Interests towards Listenning Skill}

The result of study shows there is an influence of the interaction between learning techniques and reading interests in students' English listening skills. This is evidenced by the value of $\mathrm{F}$ count $(\mathrm{Fo})=6.480$ greater than $\mathrm{F}$ table $=4.210$ (at a significant level $\alpha=0.05$ ). This causes the null hypothesis is rejected and as a consequence the research hypothesis is accepted.

The interaction between learning techniques and reading interests in students' English listening skills appears on the graph of the results of hypothesis testing where the four points which are the average values of listening skills from each group intersect. This can not be separated from precisely a learning technique closely related to student reading interest. The interaction between learning techniques and reading interests towards listening skills is caused by the formed schemas of students who have interest in reading. Furthermore, the schema is closely related to the characteristics of groups of students who follow the learning process whether through dictogloss or traditional dictation techniques.

According to (Harmer, 2001) the schema is prior knowledge or knowledge that already exists in individual acquired through experience. The formed schemas are very useful in helping students understand situations that often occur and are well known. In the listening process, the schema functions to help listeners understanding the information they hear. Rost in 
(Gilakjani \& Ahmadi, 2011) defines listening as a process of receiving, constructing, representing and negotiating the meaning of heard information. Listening is included in receptive skills. Listening activities require listeners to understand the information conveyed by the speaker. For this reason, to make students can listen to information and understand it well, students must have knowledges that can be obtained through activities such as reading books, watching news or listening to radio broadcasts that provide input in the form of vocabularies and schematic knowledges. Then listeners can favor existing knowledge to facilitate in understanding information with the help of their own knowledge about the new knowledge they get. Listening activities are also inseparable from the use of varied learning techniques to activate students' schemas.

As (Richard \& Renandya, 2002) stated technique is a method used by instructors to direct students to the results to be achieved. The use of learning techniques such as dictogloss techniques can be an option in improving the ability to understand the listened information. Students who have good reading interests can display performance in listening activities because the formed schemas facilitate them in understanding process. In other words, reading interest possessed by students can well contribute to the appropriate listening techniques. This shows the influence of interactions between learning techniques and reading interests towards English listening skills.

\section{CONCLUSION}

Based on the results obtained in this study, it can be concluded as follows. First, there are differences in the average scores of listening skill between groups of students taught with dictogloss technique and groups of students taught with traditional dictation techniques. This shows the difference in the treatment between dictogloss learning and traditional dictation has an influence entirely on students' listening ability. Second, there is an influence of the interaction between learning techniques and reading interests in students' English listening skills. The influence of occuring interaction shows at a certain level of reading interest there are differences in listening skills due to the influence of differences in treatment of learning techniques. Third, the group of students who have a high reading interest taught with the dictogloss technique have a higher average score of listening skills than those taught with traditional dictation techniques. Fourth, for students with low reading interests, there is no significant difference in the average of listening skills between those who are taught with the dictogloss and taught with traditional dictation.

These conclusions indicate the learning techniques consisting of dictogloss and traditional dictation techniques has an influence and implications towards English listening skills in students on 4th semester of English Language and Literature Department. The influence of interaction between learning techniques and reading interests towards students' English listening skills shows a learning technique have an influence on a certain level of reading interest. Based on this description, it shows the difference between the dictogloss and traditional dictation techniques as a learning technique cannot entirely reduce or improve students' English listening skills. However, at a certain level of reading interest, it can give an influence, especially on the level of high reading interest.

In general, it can be concluded to improve English listening skills at the student level can be using the dictogloss technique also by considering the level of students' interest in reading. In particular, students with high reading interest, applying the dictogloss is more effective than traditional dictation techniques. On the one hand, students with low reading interest can be taught the dictogloss and traditional dictation techniques.

Based on the described conclusions, researcher can submit some suggestions as follows. In improving students' English listening skills, lecturers can apply learning techniques both with dictogloss and traditional dictation techniques. However, if learning the English listening skill is tended for students with high reading interest, it is better to use the dictogloss technique. This research can not be separated from limitations and weaknesses. To obtain empirical data and broader knowledge about the effectiveness of a learning technique in learning and teaching process especially in the subject of listening to English, it is necessary to carry out various further studies at the student level to obtain generalizable results. And, for curriculum planners or policy makers should consider the results of research to be used as a reference in the planning and developing the education in the future.

\section{BIBLIOGRAPHY}

Alex Wahyu Wibowo, M. (2012). Penerapan Teknik Dictogloss untuk Meningkatkan Keterampilan Menyimak Bahasa Arab di Madrasah Aliyah Negeri. Journal of Arabic Learning and Teaching, 1(1), 1-7.

Andayani. (2015). Problem dan Aksioma Dalam Metodologi Pembelajaran Bahasa Indonesia. Yogyakarta: Deepublish. Bataineh, R. F. (2016). The Effect of Dictogloss on Jordanian Practicers and Students' Writing Performance. Education and Training, (June), 1-11.

Brown, H. D. (2004). Language Assessment: Principles and Classroom Practices. New York: Pearson Education.

Cain, S. C., \& Hutt, W. G. (2005). An Overview of the Conative Domain. Educational Psychology Interactive, 1-20.

Cottrell, S. (2001). Teaching Study Skills and Supporting Learning. New York: Palgrave.

Dai, W. (2013). Correlates of the Reading Interest of Chinese High School Students in International Schools. Asian Social Studies, 9(3), 164-176. https://doi.org/10.5539/ass.v9n3p164

Dewi, R. S. (2014). Teaching Writing Throught Dictogloss. IJEE, 1, 65-76. 
Gilakjani, A. P., \& Ahmadi, M. R. (2011). A Study of Factors Affecting EFL Learners' English Listening Comprehension and the Strategies for Improvement. Language Teaching and Research, 2(5), 977-988. https://doi.org/10.4304/j1tr.2.5.977988

Harmer, J. (2001). The Practice of English Language Teaching. Harlow: Pearson Education.

Holden, W. (2015). Extensive Listening: A New Approach to an Old Problem. English Language Teaching, $299-312$. Retrieved from http://www.hmt.u-toyama.ac.jp/kenkyu/kiyo49/william49.pdf

Jibir-daura, R. (2013). Using Dictogloss As An Interactive Method of Teaching Listening Comprehension. Language and Literary Study, 4(2), 112-116. https://doi.org/10.7575/aiac.alls.v.4n.2p.112

Khairuddin, Z. (2013). A Study of Students ' Reading Interests in a Second Language. English Language, 6(11), 160-170. https://doi.org/10.5539/ies.v6n11p160

Nation, I. S. P., \& Newton, J. (2008). Teaching ESL / EFL. In World Englishes.

Richard, J. C. (2001). Curriculum Development in Language Teaching. New York: Cambridge University Press.

Richard, J. C., \& Renandya, W. A. (2002). Methodology in Language Teaching. In Methodology in Language Teaching: An Anthology of Current Practice. https://doi.org/10.1017/cbo9780511667190

Schunk, Dale.H, E. a. (2012). Motivasi dalam PendidikanTeori, Penelitian, dan Aplikasi. Jakarta: PT.Indeks.

Smith, D. (2010). Smith-Pair-Dictation Activities for Teaching English to University Students. Retrieved from http://iteslj.org/Techniques/Smith-Dictation.html

Stamboel, C. S. (1990). Prinsip dan teknik pengukuran dan penilaian di dalam dunia pendidikan. Mutiara Sumber Widya. Jakarta: IKAPI.

Tomlinson, B. (2003). Developing Materials for Language Teaching. London: Cromwell Press.

Vasiljevic, Z. (2010). Dictogloss as an Interactive Method of Teaching Listening Comprehension to L2 Learners. English Language Teaching, 1(1), 41-52. Retrieved from http://www.ccsenet.org/elt

Woolfolk, A. (2009). Educational Psychology: 10th Edition. Boston: Pearson Education.Inc. 